\title{
WORK AND TECHNOLOGY: A BIBLIOGRAPHICAL ESSAY
}

A complete library of writings on the interface between work and technology-would include everything from Aristotle's reflections in the Nichomachean Ethics about machine replacements for slaves up to the latest rationale for automation. The task of producing a definitive catalogue for that library would be not Herculean but Procrustean in view of the fluid definitions of "work" and of "technology," the many related topics that touch on either, and the wide variety of specialists who have addressed them. But only a subset of these works contain or invite deliberations with philosophical import; and fewer still are authored by professional philosophers. Such qualifications notwithstanding, there does exist a literature that can be subsumed under the title: Work and Technology in Philosophical Perspective.

Any attempt to neatly categorize such literature would be more pedantic than illuminating at this stage. But it is possible to suggest within a continuum three different areas of emphasis with which a particular writing might be identified, namely, philosophical deliberation with regard to: (1) the incorporation of technology into work processes; (2) the comparative value of work and technology respectively; and (3) the appropriate "division of labor" between work and technology in the future.

These areas are not mutually exclusive; each inevitably points to the others. How they differ can be suggested by a kind of stylized chronology. On the assumption that a society's values with regard to work are fairly well established, the introduction of a work-related technology typically generates philosophical reflection in direct proportion to the perceived gravity of its consequences. On the first level of philosophical reflection are addressed technical and ethical questions about the actual or eventual impact of technology on work. Once this impact is reasonably well understood, more abstract questions arise about the comparative value of work and technology, respectively, and about the values that underly social commitment to either of these. Such questions having been adequately addressed, one is then faced with a policy-oriented, and potentially utopian, question: what should be the relationship 
between work and technology in the future? A philosophical consideration of the relationship between technology and work will inevitably touch on all three areas; but it might emphasize only one or two of them.

\section{PUTTING TECHNOLOGY TO WORK}

The impact of technology on work may be studied with an emphasis on (a) the work impacted upon; or (b) the technology having the impact.

\section{A. Work as Affected by Technology}

The most basic philosophical claim about the impact of technology on work is that tool-making is somehow the evolutionary source of those species-specific traits that make human work possible. But tool-making is itself labor; so why not recognize labor as the origin of culture? Known as the labor theory of culture, this very claim was suggested by Karl Marx and developed by Friedrich Engels. Charles Woolfson, a sociologist, reviews the evidence in his The Labour Theory of Culture: $A$ Re-examination of Engels's Theory of Human Origins (London: Routledge \& Kegan Paul, 1982). See also Clifford Geertz, 'The Impact of the Concept of Culture on the Concept of Man', in New Views of the Nature of Man, ed. J. R. Platt (Chicago and London: University of Chicago Press, 1965), pp. 93-118. Singularly important as a philosophical refinement of this originary hypothesis is Georg Lukaćs's study of "the teleology of labour," published posthumously as The Ontology of Social Being: 3. Labour (trans. David Fernbach; London: Merlin Press, 1980).

In a broad sense any organization of a workforce constitutes a social technology that affects work in various ways. The systematic utilization of slave labor to construct a pyramid or to propel a galley ship are familiar examples; as are the bureaucracies that sociologists from Weber to Ellul have analyzed. These bureaucracies, viewed as structured career ladders, are the subject of Employing Bureaucracy: Managers, Unions, and the Transformation of Work in American Industry, 1900 1945, ed. Sanford M. Jacoby (New York: Columbia University Press, 1986).

The implications of such human-based technologies have been studied philosophically to some extent. In a section of the Grundrisse recently published as Pre-Capitalist Economic Formations (trans. Jack 
Cohen; London: Lawrence \& Wishart, 1964), Karl Marx proposed a dynamic theory of pre-capitalist economic formations. That theory is brought up to date against the background of subsequent research by Barry Hindess and Paul Q. Hirst, Pre-Capitalist Modes of Production (London: Routledge \& Kegan Paul, 1975).

Related to these considerations are all the utopian writings that have proposed an allegedly better way to organize people to accomplish the work that needs to be done in a way most congenial to the people involved. An excellent introduction to this literature is Frank E. Manuel and Fritzie P. Manuel's 896-page study, Utopian Thought in the Western World (Cambridge, MA: Harvard/Belknap, 1979), which includes a helpful bibliography. More focused on the question of organizing work to the benefit of the community is J. C. Davis, Utopia and the Ideal Society: A Study of English Utopian Writing, 1516-1700 (Cambridge: Cambridge University Press, 1981); and, for example, Stanley Buder's account of a company town, Pullman: An Experiment in Industrial Order and Community Planning, 1880-1930 (Oxford: Oxford University Press, 1967).

More overtly concerned with methodology are those who dream of getting maximum productivity out of the workforce through some version of engineering. This dream had already been recorded in such works as Charles Babbages' On the Economy of Machinery and Manufactures (1832): Frederick Winslow Taylor's Scientific Management (1911); and, with a focus on management. Thorstein Veblen's The Theory of the Leisure Class $(1899,1912)$ and especially his The Engineers and the Price System (1923).

The classical economists fostered just this way of viewing the impact of technology on work with their respective versions of a labor theory of value. The issues explored in that context are carefully articulated by Ronald L. Meek, Studies in the Labor Theory of Value (2nd ed.; New York/London: Monthly Review Press, 1965). In Volume I of Capital (trans. Ben Fawkes; New York: Random House, 1977), Karl Marx supports his critique of capitalism by means of what may be the first detailed analysis of the impact of new technologies on working class individuals and families. Subsequent developments are insightfully evaluated from the natural law perspective by Yves R. Simon, Work, Society and Culture, ed. Vukan Kuic (New York: Fordham University Press, 1971).

The long ignored economic implications of Marx's labor theory of 
value have in recent years been reintroduced into Western economics by means of linear reproduction models of a capitalist economy that take into account class conflict as well as efficiency and mutual satisfaction. See Robert Paul Wolff's Understanding Marx (Princeton, NJ: Princeton University Press, 1984). Analysis of labor as a market phenomenon is, of course, a standard concern of economists, some of whom even analyze worker ownership. See Ugo Pagano, Work and Welfare in Economic Theory (New York/Oxford: Basil Blackwell, 1985); and Norman J. Ireland and Peter J. Law, The Economics of LabourManaged Enterprises (London and Canberra: Croom Helm, 1982), which includes a helpful bibliography. But the economics of labor has not been of great interest to philosophers. It is barely mentioned, for example, in Daniel M. Hausman, ed., The Philosophy of Economics: An Anthology (Cambridge: Cambridge University Press, 1984.)

Marx's theory of alienation has generated a great deal of theorizing among sociologists and philosophers but far less among Marxists who associate the notion with the early ("humanist") Marx. See Erich Fromm's introduction to the early manuscripts in Marx's Concept of Man (New York: Ungar, 1961). In recent years some promising and creative theorizing about work centers around the notion of alienation and its close cousins, estrangement and reification. Kostas Axelos focuses on Marx in Alienation, Praxis and Techne in the Thought of Karl Marx (trans. Ronaid Bruzina; Austin and London: University of Texas Press, 1976). The Marxist literature is reviewed by Richard Schacht in his Alienation (New York: Doubleday, 1971). Two international, crossdisciplinary conferences resulted in proceedings edited by R. Felix Geyer and David Schweitzer: Theories of Alienation: Critical Perspectives in Philosophy and the Social Sciences (The Hague: Martinus Nijhoff, 1976), and Alienation: Problems of Meaning, Theory and Method (London/Boston/Henley: Routledge \& Kegan Paul, 1981).

Of philosophical significance in the latter work are: Peter Christian Ludz's review of the positive meanings of alienation in the history of philosophy; Richard Schacht's distinction between a descriptive and an evaluative concept of alienation; John Torrance's preference for a structural sociological theory detached from "alienation"; John Horton and Manuel Moreno's assessment of the role of alienation in the thought of Althusser and Braverman; Mihailo Markovic's insistence upon the need for "self-determination" beyond workers' participation, control, or even self-management; and Walter R. Heinz's argument that "pre- 
occupational socialization prepares the individual for a normative acceptance of the conditions of alienated work."

Of related import are two articles in a volume of The Philosophical Forum 10, nos. 2-4 (Winter-Summer, 1978-1979) devoted to the topic of work: Frederick M. Gordon, 'Marx's Concept of Alienation and Empirical Sociological Research' (pp. 242-264); and Judith Buber Agassi, 'Alienation from Work: A Conceptual Analysis' (pp. 265-305; includes responses), which discusses the theoretical dispute among Marxists over the revolutionary potential of job dissatisfaction. In disagreement with André Gorz, Joachim Israel insists that in the absence of class consciousness, job dissatisfaction will never lead to revolution: Alienation: From Marx to Modern Sociology: A Macro-Sociological Analysis (Boston: Allyn and Bacon, 1971).

Directly interrelating alienation and technology is Simon Marcson's Automation, Alienation and Anomie (New York: Harper \& Row, 1970) and Jon M. Shepard, Automation and Alienation: A Study of Office and Factory Workers (Cambridge, MA: MIT Press, 1971). Related to these studies is the work of social historians and others who, ironically, attribute the absence of a working class consciousness in the United States to the "homogenizing" effect of various new technologies. See David M. Gordon, Richard Edwards, and Michael Reich, Segmented Work, Divided Workers: The Historical Transformation of Labor in the United States (Cambridge: Cambridge University Press, 1982). For alternative perspectives, see David Montgomery, Workers' Control in America (Cambridge: Cambridge University Press, 1979); Wolfgang Abendroth, A Short History of the European Working Class (New York and London: Monthly Review Press, 1972); and Alejandro Portes and John Walton, Labor, Class, and the International System (New York: Academic Press, 1981), which includes an extensive bibliography.

In contrast to Engels and his successors, Lewis Mumford looks to play rather than to work for the etiology of thinking, e.g., in The Myth of the Machine: Technics and Human Development (New York: Harcourt Brace Jovanovich, 1967). In this respect he justifies the preference of (bourgeois) philosophers for studying not the process of work but that of thought. In particular, philosophers (and others) have for centuries been exploring the technology of thinking. Ramon Lull, Leibniz, Pascal, Peirce, Turing and others have speculated about the possibility of building a machine that could accomplish at least some of the feats we attribute to human thinking. This speculation, today being concentrated 
on AI research, is encouraged by the thesis of $\mathrm{J}$. O. de La Mettrie, L'Homme Machine: A Study in the Origins of an Idea (critical edition; Princeton NJ: Princeton University Press, 1960).

Entry into this literature is facilitated by the bibliographical information provided in Carl Mitcham and Alois Huning, eds., Philosophy and Technology II: Information Technology and Computers in Theory and Practice (Dordrecht: D. Reidel, 1986), pp. 307-339. See in particular Irene Taviss, Technology and Work (Cambridge, MA: Harvard University Press; originally published as Research Review No. 2, Winter, 1969); Alfred Chapuis and Edmund Droz, Automata: A Historical and Technological Study (trans. Alec Reid; Neuchatel: Editions du Griffon, 1958); and Egmont Hiller, Automaten und Menschen (Stuttgart: Deutsche Verlag-Anstalt, 1958).

In general, analyses by philosophers tend to be more skeptical than are those of technical experts in the "brain machine" industry about the level of competence that such machines might attain. See in this regard the Stanford Research Institute, Management Decisions to Automate (Project No. ISU-4530, Menlo Park, CA: SRI, 1964), and the Carnegie-Mellon University study, cited below. Joseph P. Engelberger, a robot manufacturer, touts the labor saving implications of his wares in Robotics in Practice (New York: American Management Association, 1980); Engelberger's heritage may also be learned from Henry Elsner, The Technocrats: Prophets of Automation (Syracuse, NY: Syracuse University Press, 1967).

\section{B. The Extent of Technology's Impact on Workers}

Whatever the likelihood of a perfect brain machine, we already need to ask what impact even imperfect thinking machines have on human work and workers. The impact may be considered positive in many respects; but it is also likely to be negative. Whence the ambivalence of Robert Hugh Macmillan's work entitled Automation, Friend or Foe? (Cambridge: Cambridge University Press, 1956). Just as ambivalent is a 1984 study by the U.S. Office of Technology Assessment, Computerized Manufacturing Automation: Employment, Education and the Workplace, which distinguishes and evaluates four basic strategies the government might adopt: laissez faire (identified with current policies); (2) technology-oriented, i.e., emphasis on programmable automation development and use; and (3) resource-oriented, i.e., "upfront atten- 
tion to education and the work environment, and job creation"; or (4) a combination of items (3) and (4). Ongoing analysis of these and other related issues will be the function of a promising new semiannual publication entitled Technology, Work and Employment, edited by Colin Gill and published by Basil Blackwell.

H. J. Habakkuk's American and British Technology in the Nineteenth Century: The Search for Labor Saving Inventions (Cambridge: Cambridge University Press, 1962) lent credence a century later to the validity of Marx's thoughts about technology's impact on workers. But at the time many others foresaw only the benefits of the coming automation: e.g., Leon Bagrit, The Age of Automation (New York: Mentor, 1965); or, like George Terborgh in Automation Hysteria (New York: Norton, 1966), they chastised those who expected a more negative impact. More recently, automation is held blameless for any future unemployment in a management-sponsored study by $\mathrm{H}$. Allan Hunt and Timothy L. Hunt, Human Resource Implications of Robotics (Kalamazoo, MI: W. E. Upjohn Institute for Employment Research, 1983), and the problem is found only mildly worrisome in a Carnegie-Mellon University study entitled The Impacts of Robotics on the Workforce and Workplace (Pittsburgh, 1981).

Today few responsible analysts of this process deny that worker displacement is an inevitable short-term consequence of introducing labor saving technology. See, for example, Colin Gill, Work, Unemployment and the New Technology (London: Basil Blackwell, 1985). But in general social scientists other than those with Marxist leanings have been rather blasé about the long-term impact of technology on work. Typical in this respect are the writings of Herbert A. Simon and John Diebold. Daniel Bell practically eliminates industrial work in his vision of a society run by science-sensitive professionals, The Coming of PostIndustrial Society (New York: Basic Books, 1973); but he ignores the worker displacement that scenario implies. However, the labor process claim (see below) is carefully evaluated against the background of sociological theories about work by Stephen Hill, Competition and Control at Work: The New Industrial Sociology (Cambridge, MA: MIT Press, 1981). And political sociologist Claus Offe answers affirmatively his own question: 'Work: The Key Sociological Category?' in Disorganized Capitalism: Contemporary Transformations of Work and Politics (Cambridge, MA: MIT Press, 1985), pp. 129-150.

The range of possible impacts of technology on work can be gleaned 
from Annette Harrison, Bibliography on Automation and Technological Change and Studies of the Future (Rand Paper P-3365-3; Santa Monica, CA: Rand, 1967; Springfield, VA: Clearinghouse for Federal Scientific and Technical Information, U.S. Dept. of Commerce, 1968); and ROBOMATICS, a state-of-the-art microfiche service available in technological libraries and accessible via indexes and abstracts.

More alert to negative consequences are defenders of the labor movement, among whom must be included such humane geniuses as Norbert Wiener. Especially in his The Human Use of Human Beings (Boston: Houghton Mifflin, 1950) and God \& Golem, Inc. (Cambridge, MA: MIT Press, 1964), Wiener joins a long tradition of writers who have seen clouds on the horizon because of the unregulated introduction of new technology into the workplace: e.g., Georges Friedmann, Industrial Society: The Emergence of the Human Problems of Automation (trans. Harold L. Sheppard; Glencoe: Free Press, 1955); Stuart Chase, Men and Machines (New York: Macmillan, 1943); Elliott Dunlap Smith, Technology and Labor: A Study of the Human Problems of Labour Saving (London: Oxford University Press, 1939); George E. Bamett, Chapters on Machinery and Labor (1926, reprinted 1969 by Southern Illinois University and Feffer \& Simons), which focuses on the printing, stonecutting and bottling industries; and, in the preceding century (in addition to Marx), John Cameron Simonds and John T. McEnnis, The Story of Manual Labor (Chicago: R. S. Peale \& Co., 1887); and Henry George's Progress and Poverty (1879). More recent warnings are those of Ben B. Seligman, Most Notorious Victory: Man in an Age of Automation (New York: Free Press, 1966); Robert Howard, Brave New Workplace (New York: Viking, 1985), which considers both workplace health and safety and worker displacement; Joan M. Greenbaum, In the Name of Efficiency: Management Theory and Shopfloor Practice in Data-Processing Work (Philadelphia: Temple University Press, 1979); and Harley Shaiken, Work Transformed: Automation \& Labor in the Computer Age (Lexington, MA: D.C. Heath, 1986).

Typical of union responses to the displacement of workers by technology are the following: John Evans, Negotiating Technological Change (Brussels: European Trade Union Institute, 1982), and two publications of the AFL-CIO Department for Professional Employees (both published Washington, DC, 1981): Kevin Murphy, Technological Change Clauses in Collective Bargaining Agreements; Dennis Chamot and Michael D. Dymmel, Cooperation or Conflict: European Experiences with 
Technological Change at the Workplace. See also Benjamin Sollow Kirsh, Automation and Collective Bargaining (New York: Central Book, 1964), and, for purposes of comparison, Milton J. Nadworny, Scientific Management and the Unions, 1900-1932 (Cambridge, MA: Harvard University Press, 1955). The respective approaches of labor, management, and government are studied in Technological Change: The Tripartite Response (Washington, DC: International Labor Office, 1985).

The impact of labor saving technology on women in particular is being studied today as it was by Marx and others a century ago. See, for example, Heather Menzies, Women and the Chip: Case Studies of the Effects of Informatics on Employment in Canada (Montreal: Institute for Research on Public Policy, 1981), and two studies of work in the home: Ruth Schwartz Cowan in More Work for Mother (New York: Basic Books, 1983) and Susan Strasser, Never Done (New York: Pantheon, 1982). These and many other related studies Joan Rothschild incorporates into a groundbreaking anthology, Machina ex Dea: Feminist Perspectives on Technology (New York: Pergamon, 1983).

Somewhat more polemical is research that focuses on what is called the labor process. In Marxist parlance this has to do with the thesis that the ruling class introduces technology for the explicit purpose of controlling and when possible dispensing with workers. Seminal for recent research along these lines is Harry Braverman's Labor and Monopoly Capital (New York/London: Monthly Review Press, 1974), which argues that management decisions to introduce new technology have resulted in the "deskilling" of the workforce, that this result is intentional on the part of management, and that it is now reaching beyond the assembly line into the office. Follow-up studies include these works: Andrew Zimbalist, ed., Case Studies on the Labor Process (New York/ London: Monthly Review Press, 1979), and Les Levidow and Bob Young, eds., Science, Technology and the Labour Process: Marxist Studies, 2 vols. (London: Free Association Books, and Atlantic Highlands, NJ: Humanities Press, 1981 and 1985). Historical studies in this perspective include Dan Clawson, Bureaucracy and the Labor Process: The Transformation of U.S. Industry, 1860-1920 (New York and London: Monthly Review Press, 1980), and David F. Noble's studies, of the engineering profession in America by Design (New York: Knopf, 1977) and of numerical machine control in Forces of Production (Knopf, 1984). Challenging the explanatory potential of this thesis of the managerial 
quest for control (rather than for profit) are articles in Stephen Wood, ed., The Degradation of Work? Skill, Deskilling and the Labour Process (London: Hutchinson, 1982), which includes a bibliography.

Variations on the labor process theme are found in the writings of a number of philosophers. Anthony Skillen writes out of this perspective in 'The Politics of Production', a chapter of Ruling Illusions (Atlantic Highlands, NJ: Humanities Press, 1978). Mark Okrent, in 'Work, Play and Technology' (The Philosophical Forum 10, nos. 2-4 (Winter-Summer, 1978-1979), 321-340), draws upon Hegel and Heidegger to argue that managers play rather than work in a technological society. Adina Schwartz prefers worker autonomy over an unrestricted quest for productivity in 'Meaningful Work', Ethics 92 (1982). Edmund Byme views the displacement of all workers as the ultimate goal implicit in managerial workforce policy in 'Utopia without Work? Myth, Machines and Public Policy', Research in Philosophy and Technology vol. 8, ed. P. T. Durbin (Greenwich, CT: JAI Press, 1985, pp. 133-148). Jon Elster analyzes Marxist theories, among others, in Explaining Technical Change: $A$ Case Study in the Philosophy of Science (Cambridge: Cambridge University Press, 1983).

More generally, labor saving technology may encourage policies that regulate access to employment, e.g., those with regard to welfare, immigration, and equal employment opportunity. Whence the relevance here of studies of employment-related issues by ethicists and social and political philosophers. Most of these tend to support the status quo, in part because the authors seldom address the underlying issues about work. An exception in this regard is James W. Nickel, 'Is There a Human Right to Employment?' in The Philosophical Forum 10 (Winter-Summer, 1978-1979). Nickel, however, makes wealth a precondition for any such right. Compare Barbara Dinham and Colin Hines, Agribusiness in Africa (Trenton, NJ: Africa World Press, 1984).

Illustrative of the tendency among philosophers to rationalize the status quo with regard to employment are two anthologies: Marshall Cohen, Thomas Nagel, and Thomas Scanlon, eds., Equality and Preferential Treatment (Princeton, NJ: Princeton University Press, 1976), and Barry Gross, ed., Reverse Discrimination (Buffalo, NY: Prometheus, 1977). More balanced than works by Nicholas Capaldi and Alan $\mathrm{H}$. Goldman on this subject is Robert K. Fullinwider, The Reverse Discrimination Controversy: A Moral and Legal Analysis (Totowa, NJ: Rowman \& Littlefield, 1980). 
Serious philosophical consideration of this issue should take into account the data studied in Jonathan $\mathrm{H}$. Turner and Charles $\mathrm{E}$. Starnes, Inequality: Privilege and Poverty in America (Santa Monica, CA: Goodyear, 1976), the reflections on equality in The Concept of Equality, ed. William T. Blackstone (Minneapolis: Burgess, 1969), the meticulous analysis by Douglas Rae et al., entitled Equalities (Cambridge, MA: Harvard University Press, 1981), and the legal survey by Kent Greenawalt, Discrimination and Reverse Discrimination (New York: Knopf, 1983).

Frances Fox Piven and Richard A. Cloward elucidate the relationship between welfare policy and work in Regulating the Poor (New York: Vintage, 1971). For historical background see Karl de Schweinitz, England's Road to Social Security, 1349 to 1947 (Philadelphia: University of Pennsylvania Press, 1947); Martha J. Soltow and Susan Gravelle, Worker Benefits: Industrial Welfare in America, 1900-1935 (Metuchen, NJ: Scarecrow, 1983). Two philosophers have addressed the question of welfare rights in some detail: Nicholas Rescher looks for criteria in Welfare Rights (Pittsburgh: University of Pittsburgh Press, 1972), and Carl Weliman proceeds more analytically in Welfare Rights (Totowa, NJ: Rowman and Littlefield, 1982). U.S. immigration policies are the subject of two works: John Scanlan and Gil Loescher, Calculated Kindness (New York: Free Press, 1986); and The Border That Joins: Mexican Migrants and U.S. Responsibility, eds. Peter G. Brown and Henry Shue (Totowa, NJ: Rowman \& Allanheld, 1982).

\section{THE VALUE OF WORK}

As technology makes possible less labor-intensive production, the value of work is inevitably called into question. This questioning has not resulted in any uniform or consistent set of answers. But the types of responses are comparatively few in number. Here they may be reduced to two: (a) the synchronist view that technology has changed only the conditions of work (for better or worse) and not the traditional value of work; and (b) the diachronist view that technology makes traditional evaluations of work irrelevant and inappropriate. Not falling neatly on either side are (c) certain feminist studies, especially those that deal explicitly with the basic concepts of patriarchy or reproduction. 


\section{A. Synchronist Evaluations of Work}

Characteristic of the synchronist evaluation of work is the body of literature that stresses the value of craftsmanship even in a technologically transformed environment. This nostalgia for craftsmanship is seen today in such works as D. M. Dooling, ed., A Way of Working (Garden City, NY: Doubleday, 1979), Tracy Kidder, The Soul of a New Machine (Boston: Little, Brown, 1981; New York: Avon, 1982), and a century ago in the writings of British men of letters William Morris and John Ruskin.

Robert M. Pirsig's philosophical novel, Zen and the Art of Motorcycle Maintenance (New York: William Morrow, 1974), popularizes the view of all sorts of industrial therapists that proper attitude is the key to satisfaction in a technology-intensive environment. Norman Mailer even links this satisfaction to masculinity in his Of a Fire on the Moon (New York: NAL/Signet, 1971). This view is reminiscent of nineteenth century American writers, as studied by Leo Marx in The Machine in the Garden (Oxford: Oxford University Press,1964). The failure of these writers to acknowledge that the human factor can be overwhelmed by technology is counterbalanced by Jacques Ellul's well-known warnings and by E. F. Schumacher's reasoned insistence that the human need for work should continue to be met by limiting the scale of technology to what is by that very test "appropriate," e.g., in Small ls Beautiful (New York: Harper \& Row, 1973) and Good Work (New York: Harper \& Row, 1979).

Implicit in these defenses of the value of human-scale work is a normative claim made explicit under the heading of the so-called work ethic. Current debate about the work ethic centers around comparisons between the commitment of workers today and that of workers in the past with regard to the value of work. Some writers think we are not as dedicated to our work as people used to be. David Charrington chastises Americans on this score, in The Work Ethic: Working Values and Values that Work (New York: ANACOM, 1980), and expresses the hope that proper education can remedy the situation. Similar concerns have been expressed with regard to workers in other countries: Lee Smith, 'Cracks in the Japanese Work Ethic', Fortune 109 (May 14, 1984), pp. 162-168; and Susan Field, 'Egypt's Worst Enemy May be Euphoria', Euromoney (UK) (April 1979), pp. 77-82. Michael Rose, on the other hand, insists that lack of dedication to the work ethic among contemporary workers 
in no way distinguishes them from their forebears: Reworking the Work Ethic (London: Batsford Academic, 1985). See also E. Jordan Blakely, Work Ethic: Pride, or Mental Illness, ed. M. Sarah Ross (Flint, MI: Jordan Blakely, 1985); and Work Ethic: An Analytical View, 1983 (Madison, WI: Industrial Research Association, 1983).

The work ethic itself seems to have been an invention of intellectuals, who are generally supportive of its redeeming social features. Max Weber's The Protestant Ethic and the Spirit of Capitalism (trans. Talcott Parsons; New York: Scribner's, 1958; German original, 1904-1905) found motivation for entrepreneurial capitalism in the Puritan version of Calvinism: the theological notion of predestination is tied to the earthly goal of financial success. R. H. Tawney's response to Weber, The Acquisitive Society (New York, 1920), is the source of E. F. Schumacher's defense of workers' rights as against entrepreneurial irresponsibility. Emile Durkheim's The Division of Labor in Society (5 editions, 1893-1926; trans. George Simpson; New York: Macmillan Free Press, 1933) is an early attempt to base a system of ethics on an analysis of work relationships. In particular, Durkheim claims that the division of labor requires us to excel at our own specialized work both as individuals and as members of a professional group.

Durkheim's view is similar to that of Confucianism, but the reason for this cross-cultural similarity is not so easy to identify. A number of recent studies have shown how a work ethic may be founded upon the cultural heritage of a non-Western culture. See, for example, Francis L. K. Hsu, 'Filial Piety in Japan and China: Borrowing, Variation and Significance', Journal of Comparative Family Studies (Spring, 1971): 67-74; J. Elder, 'The Gandhian Ethic of Work in India', in Religious Ferment in Asia, ed. Robert J. Miller (Lawrence, KS: University of Kansas Press, 1974); and Winston L. King, 'A Christian and a Japanese-Buddhist Work-Ethic Compared', Religion 11 (July, 1981): 207-226. For a more general view of the culture-specific role of a work ethic, see Erik von Kuehnelt-Leddihn, 'La Morale du Travail: Un Problème Mondial', Cahiers de Sociologie Economique 2: 2 (December, 1971): 215-227.

\section{B. Diachronist Evaluations of Work}

Missing from synchronist evaluations of work is a willingness to acknowledge that technology has significantly and perhaps irrevocably 
transformed the conditions of work out of which traditions such as the work ethic emerged. Diachronist evaluations start with this assumption and attempt to formulate alternative norms.

A typical pro-management response is that of Michael Maccoby, The Leader (New York: Simon \& Schuster, 1981): the "craft ethic," a secularized version of the work ethic, ceased to be important in America when entrepreneurs systematized first unskilled labor and then technology to move beyond dependence upon craftsmanship to leadership. Lacking to this view is the historical perspective of Carl Bridenbaugh's The Colonial Craftsman (New York and London: University of Chicago Press, 1961; original, 1950). But neither is it as austere as Nathan D. Grundstein's attempt to justify an authoritarian approach "teleologically": The Managerial Kant: The Kant Critiques and the Managerial Order (Cleveland: Case Western Reserve University Press, 1981).

More pro-labor are the responses of historians and social scientists who take into account the background issue of who controls work. Attempts to impose a work ethic on workers in the United States have been studied, e.g., by Daniel T. Rogers, The Work Ethic in Industrial America, 1850-1920 (Chicago: University of Chicago Press, 1978), and by James B. Gilbert, Work without Salvation: America's Intellectuals and Industrial Alienation, 1880-1910 (Baltimore and London: Johns Hopkins University Press, 1977). A more global perspective is provided by Reinhard Bendix's 1956 study, Work and Authority in Industry (republished Berkeley: University of California Press, 1974). Still unsurpassed for its analysis of the relationship between ownership and control of a workplace is Adolf A. Berle and Gardiner C. Means, The Modern Corporation and Private Property (rev. ed.; New York: Harcourt, Brace \& World, 1968; original, 1932), in which a strong case is made for granting property rights to the community in which a business is located. Comparable views are expressed by more recent analysts of corporate power, but philosophical works tend to repeat the arguments of an earlier era. See, for example, Lawrence G. Becker, Property Rights: Philosophic Foundations (London: Routledge \& Kegan Paul, 1980).

The foregoing studies of work control presuppose an ongoing workplace. The instability of employment in the face of new technology and other related factors is also being taken into account, at least indirectly, in philosophical considerations of corporation and employment law. Much of this material is being incorporated into business ethics texts. 
But not all of these are equally attentive to the interests of workers. Exceptions include Patricia Werhane, Persons, Rights and Corporations (Englewood Cliffs, NJ: Prentice-Hall, 1985); Thomas Donaldson, Corporations and Morality (Englewood Cliffs, NJ: Prentice-Hall, 1982); and Milton Snoeyenbos, Robert Almeder, and James Humber, eds., Business Ethics (Buffalo, NY: Prometheus, 1983). Almost half of the latter book deals with employee rights and obligations and hiring and discharge questions. Werhane offers a balanced treatment of the rights and obligations of (a) a corporation and (b) its employees; but she writes as though recognition of a right is equivalent to its enforcement. Donaldson focuses on questions of corporate responsibility, an increasingly debated topic among philosophers; e.g., see the contributions to Corrigible Corporations and Unruly Laws, ed. Brent Fisse and Peter A. French (San Antonio, TX: Trinity University Press, 1985).

This being a rapidly changing area of law, law texts need to be regularly supplemented. Useful, however, as an introduction to American law on the subject is Alan E. Westin and Stephan Salisbury, eds., Individual Rights in the Corporation: A Reader on Employee Rights (New York: Pantheon, 1980); and to British law: Paul O'Higgins, Workers' Rights (London: Arrow, 1976); and Jeremy McMullen, Rights at Work (2nd impression with supplement; London: Pluto, 1979). A more technical treatment of American employment law for which updates would be available is Lex K. Larson and Philip Borowsky, Unjust Dismissal (Albany, NY: Matthew Bender, 1985).

The foregoing approaches disregard situations in which the workers are unionized. James B. Atleson's Values and Assumptions in American Labor Law (Amherst, MA: University of Massachusetts Press, 1983) assumes the existence of unions and shows that common-law endorsement of management rights in the United States is being perpetuated in judicial interpretations of statutory law that on its face clearly grants certain rights to employee unions. Even more intentionally philosophical in their analysis of labor law are two studies of unions as groups: Frank Tannenbaum, A Philosophy of Labor (New York: Knopf, 1951), and the doctoral dissertation of John Herman Randall, Jr., The Problems of Group Responsibility to Society (reprint; New York: Arno Press, 1969; original, 1922).

More basic still is the claim that the introduction of technology into the workplace renders obsolete any encomium of a work ethic for the simple reason that there is no longer enough work to go around. This 
concern is typically answered by asserting that new technology creates as many jobs as it eliminates. This comforting view is challenged by such studies as Barry Bluestone and Bennett Harrison, The Deindustrialization of America (New York: Basic Books, 1982), and Ian Benson and John Lloyd, New Technology and Industrial Change (London: Kogan Paul, 1983); and the debate goes on. Of philosophical interest in this debate is its impact on the work ethic and its various corollaries, e.g., with regard to welfare.

A useful guide to this issue is David Macarov, Work and Welfare: The Unholy Alliance (London/Beverly Hills: Sage, 1980). Macarov notes how we have tied welfare (meaning our personal well-being in society) to work on the basis of four specific attitudes, which he identifies as: (1) believing in the myth of needed work; (2) acquiescing in "the job scramble"; (3) viewing work as normalcy; and (4) subsuming work under morality. He calls for clear distinctions among the different meanings of work as a prerequisite to revising our attitudes about work in preparation for increased leisure leading to "an (almost) workless world."

Attention to this very possibility is the hallmark of Hannah Arendt's erudite reconsideration of ancient and mediaeval thought about work: The Human Condition (Garden City, NY: Doubleday, 1959). Arendt traces modern attitudes about work to the views of the ancient Greeks, for whom work, unlike labor, results in a product. Automation renders that distinction obsolete but reestablishes the primacy of contemplation over action. This brilliant but somewhat forced explanation of our contemporary crisis needs to be modified in light of such works as Jacques Le Goff's Time, Work \& Culture in the Middle Ages (Chicago: University of Chicago Press, 1980).

\section{Feminist Reevaluations of Work}

Feminist theory as a whole might be viewed as a reinterpretation of received doctrines regarding the appropriate allocation and evaluation of work. Explicit feminist consideration of work typically involves in some way a comparative evaluation of the work process. What is compared, however, is not the value of work past and present but the value of work commonly done by males and that commonly done by females. In this literature, accordingly, such notions as patriarchy and reproduction serve as lodestones for reinterpreting arguably male supremacist theories. 
Alison Jaggar in Feminist Politics and Human Nature (Totowa, NJ: Rowman \& Allanheld; Brighton: Harvester, 1983) discusses the different ways in which radical, socialist, and liberal feminists, respectively, account for women's subordination in terms of reproduction. In Capitalist Patriarchy and the Case for Socialist Feminism, ed. Zillah R. Eisenstein (New York and London: Monthiy Review Press, 1979), socialist feminists trace work relationships in the home to capitalist patriarchy. Zillah R. Eisenstein, in The Radical Future of Liberal Feminism (New York and London: Longman, 1981), charges liberal feminists with accepting patriarchy and thereby committing the working mother to a "double day." Diverse arguments in support of androgynous co-sharing of sex roles are presented by Mary O'Brien, The Politics of Reproduction (Boston/London: Routledge \& Kegan Paul, 1981), Nancy Chodorow, The Reproduction of Mothering: Psychoanalysis and the Sociology of Gender (Berkeley: University of California Press, 1978), and Dorothy Dinnerstein, The Mermaid and the Minotaur: Sexual Arrangements and Human Malaise (New York: Harper \& Row, 1976).

These feminist studies should be viewed on a broader canvas that includes the ideology of creativity and innovation, in which many scholars, notably Freud, have seen male supremacist implications. Carolyn Merchant uncovers some pseudo-scientific underpinnings in The Death of Nature (New York: Harper \& Row, 1979). Mircea Eliade explores the sexual symbolism of ancient mining and metallurgy in The Forge and the Crucible (trans. Stephen Corrin; London: Rider, 1962).

\section{WORK AND TECHNOLOGY IN THE FUTURE}

Work, as organized and divided into jobs, is the principal source of livelihood for many people; and as such it has long been encouraged by every institutional form of persuasion, generally in terms of the work ethic. But technology is transforming work into a scarce and possibly non-renewable resource. This, briefly, is the dilemma facing anyone who wants to prescribe an appropriate relationship between work and technology in the future.

Larry Hirschhorn solves the problem by denial. He contends in Beyond Mechanization: Work and Technology in the Post-Industrial Age (Cambridge, MA: MIT Press, 1984) that much of the talk about workers being phased out by automation is greatly exaggerated, because the new electronic technologies which are at its base actually call for more rather 
than less human involvement. However, workers will need to be better educated to deal with the complex demands that machines make on humans. Comparable optimism is expressed by Theodore Roszak in The Cult of Information (New York: Pantheon, 1986), Alvin Toffler in The New Wave (New York: William Morrow, 1980), and John Naisbitt in Megatrends (New York: Warner, 1982). More sensitive to structural complexities are the contributions to Futures for Work, ed. Geert Hofstede (The Hague: Martinus Nijhoff, 1979), and The World of Work: Careers and the Future, ed. Howard F. Didsbury, Jr. (Bethesda, MD: World Future Society, 1983).

Generally indifferent to the methodological pitfalls of prediction, philosophers who have addressed this subject tend to assume that full-time meaningful work will not be available to all who need or want it in the future.

Bernard Gendron in Technology and the Human Condition (New York: St. Martin's Press, 1977) and David Schweickart in Capitalism or Worker Control? (New York: Praeger, 1980) both argue that a version of worker control is preferable to what they view as the unacceptable impact of capitalist arrangements on the workplace.

Herbert Marcuse in One-Dimensional Man (Boston: Beacon, 1964), recognizes the short-range concerns of workers, but insists that longterm opposition to automation stands in the way of eventual attainment of a liberating utopia based on technology. This latter, however, cannot occur under capitalism: see 'The End of Utopia', one of Five Lectures by Marcuse (trans. J. J. Shapiro and S. M. Weber; Boston: Beacon, 1970).

André Gorz says technology will lead to "liberation from work"; this, however, can be achieved only within a social environment which does not yet exist (at least not generally): Paths to Paradise: On the Liberation from Work (London and Sydney: Pluto Press, 1985). In aid of this movement ad astra, Frithjof Bergmann recommends organizing the unemployed politically: see 'The Future of Work', Praxis International 3 (October, 1983): 308-323.

Jonathan Glover (see Chap. 9, 'Work', in his What Sort of People Should There Be? (New York: Penguin, 1984) envisions a society in which machines do the unpleasant work, people share other jobs, and sufficient income is made available to all. To assure that people will have intrinsically satisfying work, society may need to give preference to humans over machines even if the latter could replace the former. This view echoes that put forward a century earlier by William Morris in his novel News from Nowhere (London, 1891). 
David Braybrooke, in 'Work: A Cultural Ideal Ever More in Jeopardy' (Midwest Studies in Philosophy, vol. 7, eds. Peter A. French et al.; Minneapolis: University of Minnesota Press, 1982), shares Glover's concern about retaining meaningful work, and suggests that utilitarianism may have to provide the basis for a future "ethics of welfare."

Edmund Byrne, in 'Displaced Workers: America's Unpaid Debt', Journal of Business Ethics 4 (1984): 31-41, argues for a national commitment to solving the problem of displaced workers because business alone cannot provide enough fulltime paying jobs in the future. Comparable concerns are expressed in Francis X. Quinn, ed., The Ethical Aftermath of Automation (Westminster, MD: Newman, 1962).

More generally, Australian Barry Jones's Sleepers, Wake! Technology and the Future of Work (Melbourne: Oxford University Press, 1982) is perhaps the best recent treatment of the futurist issue, partly because it includes surveys of the impact and the value issues. Although drawing heavily on Australian data, Jones knowledgeably covers each of the three principal areas, concludes with a 22-point program for the future, and emphasizes the importance of consciousness-raising. In short, probably the one best overall introduction to the issues.

On none of these issues, of course, has the last word been said; so there is ample opportunity to add additional philosophical perspective to the complex interface between work and technology. In particular, this bibliographical review covers neither workplace health and safety, philosophical aspects of which have been studied, for example, by Mary Gibson, Nicholas Rescher, and Kristin Shrader-Frechette, nor the problem of exploitation in developing countries. Nor does it represent a systematic search of the literature in languages other than English. With regard to areas that have been covered, the author welcomes reminders of significant omissions for which he is undoubtedly but not willfully responsible.

Indiana University/Purdue University at Indianapolis 